TURIZAM

Volume 25, Issue 1

45-54 (2021)

ORIGINAL

SCIENTIFIC PAPER

\title{
Geographical Index of Concentration as an Indicator of the Spatial Distribution of Tourist Attractions in Belgrade
}

\author{
Sanja Pavlović ${ }^{A}$, Radmila Jovanović ${ }^{B}$ \\ Received: July 2020 | Accepted: March 2021 \\ DOI: $10.5937 /$ turizam25-27553
}

\begin{abstract}
The spatial structure of tourist attractions can be presented both qualitatively and quantitatively. One of the indicators of the spatial structure of tourism is the index of geographical concentration of tourist attractions. The geographical concentration of tourist attractions represents the ratio of the number of tourist attractions in the observed area and its structural parts and the total number of structural units of the analyzed area. This paper aims to determine the spatial distribution of attractions in the administrative territories of Belgrade municipalities and to establish correlations with tourist attendance. The number and spatial distribution of accommodation capacities are the largest in the central city municipalities so that the number of visitors is the largest in them. At the same time, the central city municipalities have the highest concentration of tourist attractions. For data collection, the authors used field research, OSM (Open Street Maps), Google maps, with software processing ArcGIS 10.2. The research results enabled the definition of the model of distribution of tourist attractions and indicated its application. This model of distribution of tourist attractions shows that they are mostly concentrated in the city center. This also means a small spatial connection of tourist attractions in the city center and peripheral parts.
\end{abstract}

Keywords: tourist attractions, spatial distribution, geographical index, Belgrade

\section{Introduction}

The competition of tourist values in an area, among other things, relies on the structure of the tourist resource. The structure of resources is the relationship between spatial distribution, quality, and the number of resources in a tourist destination (Shen, 2002). Starting from the 1960 , various models of the spatial structure of tourism emerged and developed (Christaller, 1964). More recently, Pan (2013a), using the methods of spatial-econometric geographical

\footnotetext{
A University of Belgrade, Faculty of Geography, Studentski trg 3/3, 11000 Belgrade, Serbia; Corresponding author: spavlovic20@gmail.com

в Independent Researcher
} 
quantitative analysis, has pointed to the distribution of selected tourist attractions in China. The same author, using the raster algorithm (GIS), analyzed the spatial accessibility of attractions in China (Pan, 2012). Using raster weighted distances, he analyzed the availability of Chinese national forest parks (Pan, 2013b).

Wang et al. (2016) performed an analysis of the spatial structure of tourist attractions in Lanzhou, based on GIS. They calculated the following: the nearest neighbour index, the index of geographical concentration of tourist attractions, the Gini coefficient, and the accessibility index. The nearest neighbour index is the basic method of studying the types of the spatial distribution of tourist attractions. In the calculation process, the theoretical distance of the nearest neighbour and the index of the nearest neighbour were determined (the ratio of the actual nearest distance and the theoretical distance of the nearest neighbour) (Yuan, Yu, 2010). The Gini coefficient is an index of comparative differences in the geographical characteristics of spatial distribution (Pan et al., 2014). The accessibility index is calculated using the total distance algorithm and refers to the shortest path based on raster data. The spatial distribution of ecotourism attractions in Anambra, Nigeria was done by Odum et al. (2018) using the closest neighbourhood analysis.

Pan et al. (2015) using GIS and quantitative analysis investigated the spatial structure of 2424 tourist attractions of China. The spatial accessibility of all tourist attractions was calculated by the method of weighted distance and ArcGIS software. They stated that Chinese tourist attractions were distributed unevenly, with a large concentration in certain regions. Zhao (2018) by researching the spatial structure of picturesque destinations in 18 cities of Henan Province determined the existence of a general pattern of differentiation.

Analyzing the location data of 9820 A-class tourist attraction locations in China, Wang et al. (2018) concluded that the spatial distribution of tourist attractions represented a cluster pattern. The pattern of the spatial distribution of tourist attractions varies depending on their ratings, i.e. valorization. Chinese tourist attractions are mainly located in the plains, near major rivers, in areas with high population density, high level of economic development, and good transport infrastructure. Spatial clustering of tourist attractions based on an algorithm consistent with their density was done by Zhu et al. (2018), using the spatial information in a Location-Based Social Network (LBSN). Natural protected areas in China are unevenly distributed, according to the research conducted by Xu and Pan (2019). More than half of the protected natural areas are located in the central and eastern provinces of China.

A study by Kang et al. (2018) identified the spatial structure of the tourist attraction system in Seoul, South Korea. Spatial patterns of distribution of the degree of centrality were investigated, which enabled the identification of points of tourist networks. Truchet et al. (2016) analyzed how tourist attractions affect the development of destination tourism and the spatial scope of the impact. They stated that the attractiveness of tourist attractions and their spatial characteristics are decisive factors for the development of tourism, distinguishing between local, widespread, and diffuse locations.

Sousa Guedes and Martin Jimenez (2015) identified the concentration points (clusters) of cultural resources in Portugal, to identify repetitive and dominant spatial patterns. The analysis shows a hierarchical and polarized network around Lisbon. Organized cultural programmes based on cultural heritage reduce the asymmetry of the space of cultural tourist attractions, historically concentrated around the Algarve region. Using the network, spatial analysis and geovisualization Kirilenko et al. (2019) grouped tourist attractions according to the interests of tourists. The study combines the attractions of Florida with the patterns of visits of tourists from different markets, introducing in addition to the spatial and behavioral dimension of research. Tourist attractions are spatially grouped and classified in a paper 
written by Peng and Huang (2017). Accuracy of grouping and classification enables the distinction of neighbouring areas with a higher density of attractions and better attendance of tourist attractions when they are unevenly distributed.

In addition to the analysis of the spatial structure of tourist attractions, it is necessary to point out some other features and classifications necessary for the theoretical definition of attractions, in the context of this scientific paper. The competitiveness of a tourist destination is influenced by a set of factors. They are marked in the scientific literature as factors of the attractiveness of a tourist destination (Mihalič, 2000; Ritchie, Crouch, 2005). Multiple tourist attractions that are related and mutually homogeneous together are called the attractiveness factors of a tourist destination. The need for grouping tourist attractions stems from their large number and heterogeneity (Krešić, 2007). Kushen (2002) believes that attractiveness factors influence the direction and intensity of tourism development in the destination.

Weber and Mikačič (1995) single out general and special factors of attractiveness. General attractiveness factors are key in examining the attractiveness of different destinations (these are most often natural attractiveness factors). Specific attractiveness factors show that factors have different importance for different destinations. The classification of attractiveness factors was proposed by the World Tourism Organization (UNWTO) and presented by McIntyre and Inskeep (1993). They highlight natural tourist resources, cultural and historical heritage in tourism, climatic conditions, infrastructure, tourist services, and facilities.

The classification of attractiveness factors is based on three approaches: ideographic (images of nature), organizational (surrounding space, attraction capacity, duration), and cognitive (perceptions and experiences of tourists) (Lew, 1987). The ideographic and organizational approaches were applied in calculating the geographical index of the concentration of tourist attractions. Ritchie and Crouch (2005) single out seven groups of tourist attractions: relief characteristics and climate, history and culture, market connections, an offer of activities, events, entertainment, and tourist suprastructure.

\section{Methods and data}

The spatial coverage of the researched topic consists of 17 municipalities of the City of Belgrade. Their total area is 322,268 ha (urban area 35,996 ha). The inner-city area consists of the following municipalities: Čukarica, New Belgrade, Palilula, Rakovica, Savski Venac, Stari Grad, Voždovac, Vračar, Zemun and Zvezdara. The outer-city area includes the following municipalities: Barajevo, Grocka, Lazarevac, Mladenovac, Obrenovac, Sopot, and Surčin.

Tourist attractions were taken from the open database maps (Google Maps, Open Street Maps), field research (data collection by GPS navigation). In methodological terms, field research was used, along with ArcGIS software processing 10.2.

The index of geographical concentration is an important indicator of the degree of concentration of tourist attractions (Wei, Hua, 2012) and can be one of the criteria for evaluating the attractiveness of a destination. However, it is used to evaluate the attractiveness of the destination as a whole, without taking into account individual attractions. The measurement of the spatial distribution of tourist attractions is done according to the formula (Wu et al., 2003; Ding et al., 2011):

$$
G=100 \sqrt{\sum_{i=1}^{n}\left(\frac{x_{i}}{T}\right)^{2}}
$$


$G$ is the geographical index of the concentration of research objects, i.e. distribution of tourist attractions, $x_{i}$ - number of tourist attractions in the observed area (in each Belgrade municipality separately), $T$ - total number of tourist attractions in all municipalities of Bel-

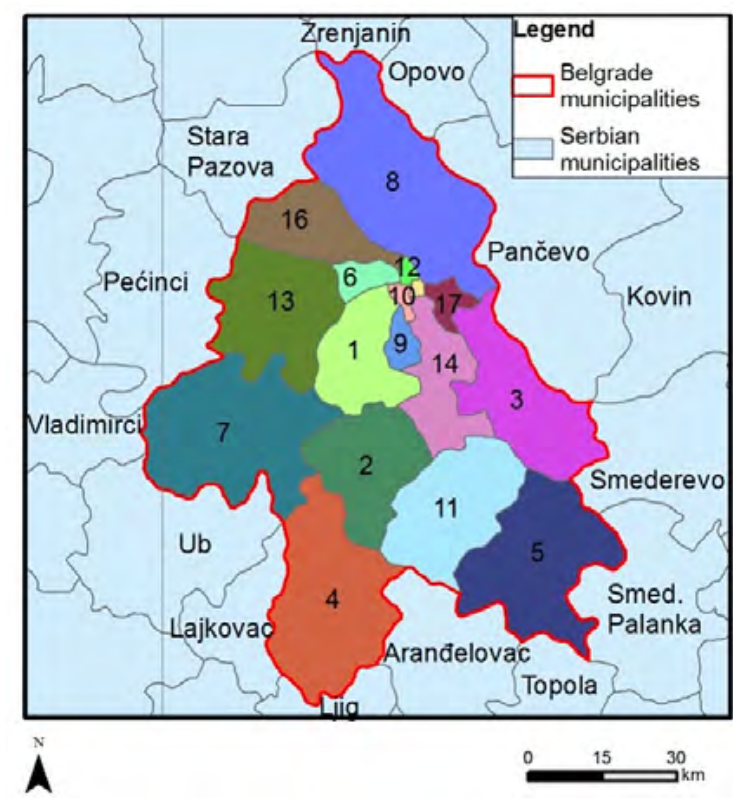

Figure 1. Position of the municipalities of the City of Belgrade Source: author's research

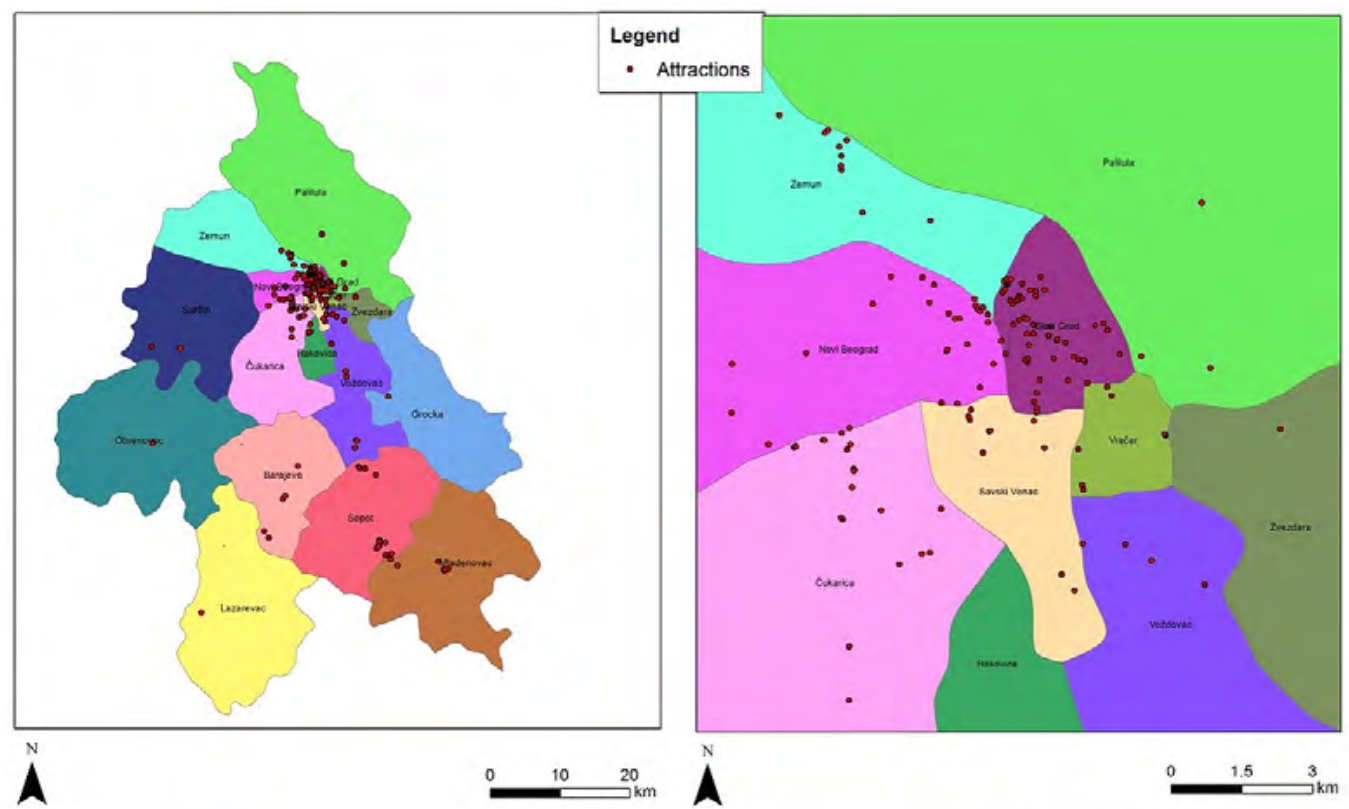

Figure 2. Distribution of tourist attractions in the municipalities of the City of Belgrade Source: author's research 
grade, $\mathrm{n}$ - total number of municipalities. The geographical index of the concentration of tourist attractions $(G)$ has values from o to 100. A higher value of $G$ shows a more concentrated distribution of research objects, and a lower value shows a higher distribution of tourist attractions. The initial assumption in the paper is that the attendance of urban municipalities directly depends on the geographical index of the concentration of tourist attractions.

\section{Results and discussion}

For this paper, the attraction basis consists of cultural-historical attractions (archaeological sites, sacral buildings, art centres, cultural monuments, fortresses, museums), natural attractions (mountains, lakes, rivers) and infrastructure (facilities for sports and entertainment recreation, facilities for respite, parks, educational facilities, cinemas, theaters). The research results of the geographical index of the concentration of tourist attractions of the City of Belgrade are shown in Table 1 and Figure 3.

Table 1. Geographical index of the concentration of tourist attractions of the City of Belgrade

\begin{tabular}{|l|c|}
\hline Municipalities & Geographical index \\
\hline Čukarica & 53,07 \\
\hline Barajevo & 13,61 \\
\hline Grocka & 2,72 \\
\hline Lazarevac & 8,16 \\
\hline Mladenovac & 12,25 \\
\hline Novi Beograd & 44,91 \\
\hline Rakovica & 10,89 \\
\hline Palilula & 27,22 \\
\hline Savski Venac & 25,85 \\
\hline Stari Grad & 99,34 \\
\hline Surčin & 12,25 \\
\hline Voždovac & 24,49 \\
\hline Vračar & 10,89 \\
\hline Zemun & 29,94 \\
\hline Zvezdara & 10,89 \\
\hline Sopot & 20,41 \\
\hline Obrenovac & 5,44 \\
\hline
\end{tabular}

Source: author's research

The research results show that the municipality of Stari Grad has the highest value of the geographical index of the concentration of tourist attractions. The concentrated distribution of tourist attractions indicates their proximity because the tourist attractions in this municipality are located in the city centre. The most visited tourist attractions of Belgrade are located in the municipality of Stari Grad: Belgrade Fortress, Knez Mihailova Street, Skadarlija, Kosančićev Venac, Republic Square, Students Square, Terazije. After the municipality of Stari Grad, the municipalities of Čukarica, New Belgrade, Zemun, Palilula and Savski Venac have the highest value of the geographical index of concentration of tourist attractions. The munic- 


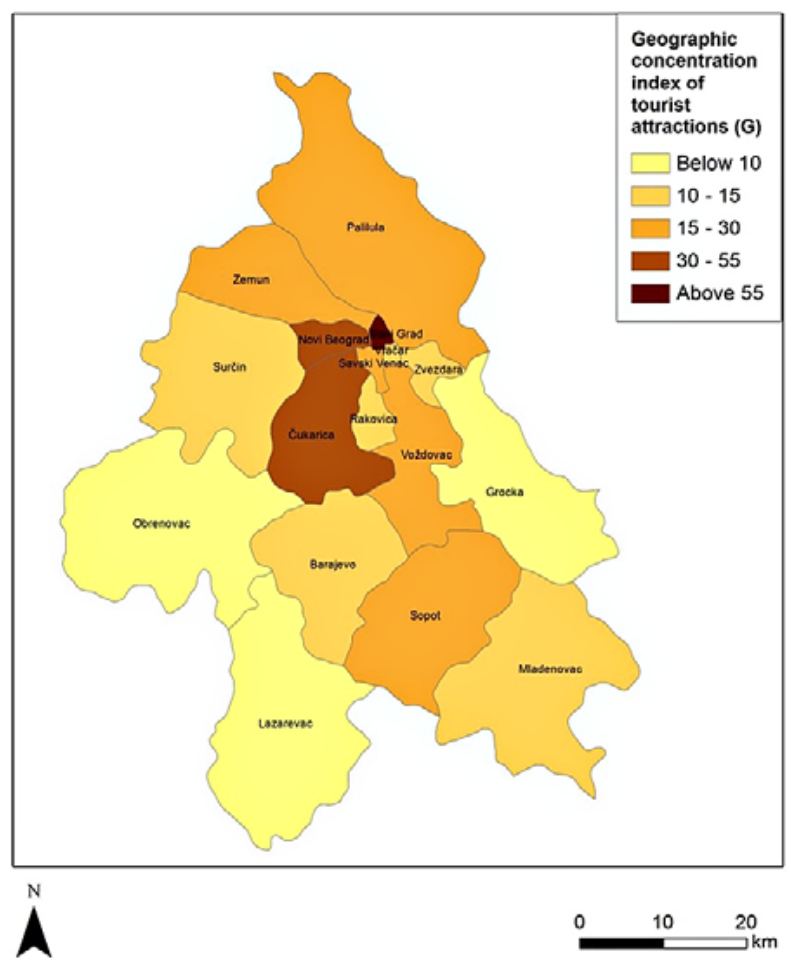

Figure 3. Geographical index of the concentration of tourist attractions in Belgrade

Source: author's research

ipalities of Grocka, Obrenovac, and Lazarevac have the lowest geographical index of the concentration of tourist attractions.

Based on the analysis performed by Truchet et al. (2016) it can be concluded that the tourist attractions of Belgrade have local, widespread, and diffuse locations. The local distribution of tourist attractions is characteristic of central city municipalities, such as Stari Grad, Čukarica, New Belgrade, Zemun, Savski Venac, Palilula. In the municipality of Voždovac, tourist attractions are widespread, and a diffuse schedule exists in the municipalities of Rakovica, Zvezdara, Sopot, Barajevo, Mladenovac, Surčin, Grocka. Although the municipalities of Čukarica, Zemun, and Palilula occupy relatively large areas, the geographical index of the concentration of tourist attractions has higher values compared to some other municipalities. This shows that tourist attractions are concentrated in a small area, closer to the city centre.

When it comes to similar research, i.e. the calculation and analysis of the geographical index of the concentration of tourist attractions in Serbia, they have not been done so far. Such research is characteristic of China. One of them was done on the example of the province of Henan, in which the index of geographical concentration of attractions had a value of 25.28 if only the most visited attractions were taken into account. There is an obvious difference in the number of tourist attractions and their spatial distribution, with the city of Henan having the most of them (Zhao, 2018). Wang et al. (2016) determined the index of geographical concentration of tourist attractions for 58 attractions in Lanzhou and obtained a value of 39.69, which showed that the attractions were concentrated. Ding et al. (2011) calculated that the index of geographical concentration of tourist attractions in Nanjing is 34.43 , indicating that the schedule is relatively concentrated. 
The attraction basis of Belgrade and the concentration of attractions have been researched in the works of other authors. However, quantitative research on the schedule of tourist attractions is not. The attraction base of Belgrade consists of cultural and historical heritage, manifestations, natural values with recreational zones, and catering facilities. Some of these attractions are in the narrower, some in the wider city area. Cultural tourist attractions dominate the tourist offer of Belgrade (Stanković, Vojčić, 2007; Joksimović et al., 2014; Pavlović, Vesić, 2019).

The research conducted by Joksimović and others (2014) shows that the most important cultural and historical heritage of Belgrade is located in the municipalities of Stari Grad, Palilula, Savski Venac, Vračar, and Zemun. Group and individual visits of tourists include tours of the Belgrade Fortress, the ambient whole of Skadarlija, the Zemun Quay. Analyzing travel blogs about Belgrade, Todorović (2015) states that the Belgrade Fortress is the most frequently mentioned tourist attraction in the city, followed by the Nikola Tesla Museum and the Temple of St. Sava. Todorović and Deđanski (2016) state that the attractions are mostly concentrated in the central parts of the city. The most visited tourist attraction is the Belgrade Fortress. Other most visited attractions are located in the area from the Belgrade Fortress to the Temple of St. Sava.

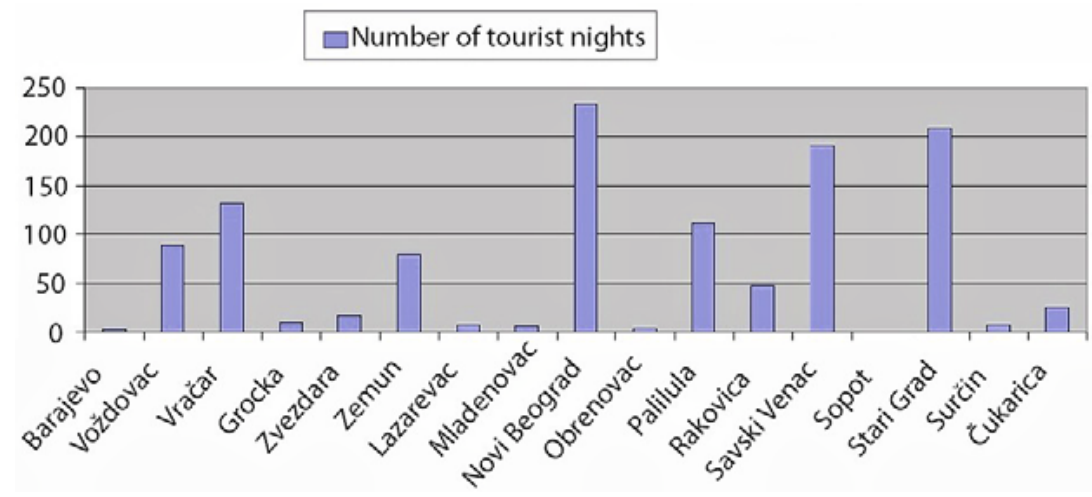

Figure 4. Tourist attendance of the municipalities of the City of Belgrade in 2018 (in thousands)

Source: Republic Bureau of Statistics (Publication Municipalities and Regions in Serbia)

Although the largest number of tourist attractions is concentrated in the city centre, the number of visitors by municipalities in Belgrade is related to the number and utilization of accommodation facilities, beds, and rooms. The number and spatial layout of hotels and hostels are the largest in the central city municipalities, so the number of visitors is the largest in them. The initial assumption in the paper that the attendance of urban municipalities directly depends on the geographical index of the concentration of tourist attractions has been confirmed, as shown by the following findings.

The largest number of visitors in 2018 was recorded in the municipalities of New Belgrade, Stari Grad, Savski Venac, Vračar, and Palilula. Apart from the municipality of Vračar, the other most visited municipalities have a relatively large geographical index of concentration of attractions.

The relatively short length of stay of tourists in Belgrade (about two nights) has a negative effect on sightseeing tours that are not in the city centre. A longer stay in Belgrade would ena- 
ble foreign and domestic tourists to see and experience a larger number of tourist motives, to realize various activities. More attention should be paid to the development of tourism in suburban settlements, especially the planning and development of tourist attractions. Their evaluation should be done and competitive advantages should be pointed out. This research could be used in defining guidelines and strategic frameworks for tourism development.

\section{Conclusion}

The spatial structure of tourist attractions affects the spatial properties of tourist activities. Their analysis can help guide tourism. The spatial structure of tourist attractions includes not only the pattern of distribution but also the spatial behaviour of tourists. It affects the speed, scope of development, temporal, and spatial distribution of attractions. The structure of tourist attractions reflects the relationship between tourism, population, urban and rural development, infrastructure construction.

The uniformity of the distribution of attractions is very small because the geographical index of the concentration of tourist attractions in Belgrade municipalities has values from 2.72 (Grocka) to 99.34 (Stari Grad). This model of distribution of tourist attractions, concentrated in the city centre, conditions the spatial structure of tourist movements and the small spatial connection of tourist attractions in the city centre and peripheral parts.

The values of the geographical index of the concentration of tourist attractions in Belgrade show that these are attractions that have local, widespread and diffuse locations. The highest values of the geographical index of tourist attractions have the municipalities in which the locality of the attractions is expressed, the average value has the municipality with widespread attractions, and the lowest values have those municipalities in which the attractions are diffusely distributed.

Further research could be focused on the classification of attractions as a basis and the calculation of the geographical index of the concentration of attractions for natural, cultural, and historical attractions, infrastructure, tourist services, and facilities. A comparison of the geographical index of the concentration of tourist attractions in two or more tourist destinations could also be the subject of research, to determine the connection between the spatial distribution of tourist attractions and regional economic development. The spatial pattern of tourist attractions is important in tourism, so the correlations of tourist attractions, traffic lines, and accommodation capacities of certain areas should be investigated, and the uneven distribution of the population should also be taken into account.

\section{References}

Christaller, W. 1964. Some considerations of tourism location in Europe: The peripheral region-under developed countries recreation areas. Regional science Association 12(1), 95-105.

Ding, L., Wang, Y., Zhang, F., Wu, X. and Tang, S. 2011. Spatial structure of tourist attractions in Nanjing, China: Based on statistical analysis of 317 tourist attractions. In: X. Li, S., Bao (Eds.), Proceedings of the 19th International Conference on Geoinformatics, (941946). Shanghai: Institute of Electrical and Electronics Engineers. doi: 10.1109/GeoInformatics.2011.5980771 
Joksimović, M., Golić, R., Vujadinović, S., Šabić, D., Jovanović-Popović, D., Barnfield, G. 2014. Restoring tourist flows and regenerating city's image: the case of Belgrade. Current Issues in Tourism 17(3), 220-233.

Jun, Y., Lin, Y.R. 2010. Research on spatial structure of national A-Grade tourist districts of Wuhan metropolitan area. Economic Geography 30(2), 324-328.

Kang, S., Lee, G., Kim, J., Park, D. 2018. Identifying the spatial structure of the tourist attraction system in South Korea using GIS and network analysis: An application of anchorpoint theory. Journal of Destination Marketing \& Management 9, 358-37o. https://doi. org/10.1016/j.jdmm.2018.04.001

Kirilenko, A.P., Stepchenkova, S.O., Hernandez, J.M. 2019. Comparative clustering of destination attractions for different origin markets with network and spatial analyses of online reviews. Tourism Management 72, 400-410.

Krešić, D. 2007. Tourism destination attractivevess factors in the function of competitiveness. Acta turistica 19 (1), 45-82. (in Croatian and English)

Kušen, E. 2002. Tourism Attraction Base. Institute of Tourism, Zagreb. (in Croatian)

Lew, A. A. 1987. A Framework of Tourist Attraction Research. Annals of Tourism Research 14.(4), 553-575.

Mcintyre, G., Hetherington, A., Inskeep, E. 1993. Sustainable tourism development: guide for local planners. UNWTO, Madrid.

Mihalič, T. 200o. Environmental management of a tourist destination: a factor of tourism competitiveness. Tourism Management 21 (1), 65-78.

Municipalities and regions in the Republic of Serbia. 2019. Republic Statistical Office, Belgrade. (in Serbian)

Odum, C.J., Akukwe, T.I., Andrew-Essien, E., Eja, I.E. 2018. Spatial Distribution of Ecotourism Resources in Anambra State: A Nearest Neighbour Analysis Approach. American Journal of Social Sciences 6(3), 29-38.

Pan, J.H. 2012. Spatial accessibility of scenic spot at 4A level and above in China. Scientia geographica sinica 32(11), 1322-1327.

Pan. J.H. 2013a. Analysis on spatial structure of A-Grade science spots in China based on quantitative geography model. Economic geography 33(9), 154-160.

Pan, J.H. 2013b. Measurements for spatial accessibility of national forest parks in China. Resources and Environment in the Yangtze Basin 22(9), 1181-1187.

Pan, J.H., Ma, C., Li, J.F. 2014. Spatial structure of A-grade tourist attractions in Gansu. Journal of Arid Land Resources and Environment 28(7), 188-193.

Pan, J.H, Li, J.F., Cong, Y. 2015. Quantitative Geography Analysis on Spatial Structure of A-Grade Tourist Attractions in China. Journal of Resources and Ecology 6(1), 12-20. DOI:10.5814/j.issn.1674-764X.2015.01.002

Pavlović, S., Vesić, M. 2019. Cultural attractions of Belgrade in focus of touristic offer. Glasnik Srpskog geografskog društva 99(1), 91-114. (in English and Serbian)

Peng, X., Huang, Z. 2017. A Novel Popular Tourist Attraction Discovering Approach Based on Geo-Tagged Social Media Big Data. International Journal of Geo-Information 6(7). doi:10.339o/ijgi6070216

Ritchie, B. J., Crouch, G. I. 2005. The competitive destination: a sustainable tourism perspective. CABI Publishing, Wallingford.

Shen, Z.P. 2002. A Study on the Structure and the Development Allocation of Tourist Resources in the Economic Belt of the New Eurasian Continental Bridge in China. Scientia geographica sinica 22(2), 176-183. 
Sousa Guedes, A., Martin Jimenez, I. 2015. Spatial patterns of cultural tourism in Portugal. Tourism Management Perspectives 16, 107-115.

Stanković, S. M., Vojčić, V. 2007. Place of tourism in the Belgrade economy. Collection of the Papers - Faculty of Geography, University of Belgrade, vol. LV, 95-104. (in Serbian)

Truchet, S., Piguet, V., Aubert, F., Callois, J.M. 2016. Spatial influence of attractions on tourism development. Tourism Geographies 18(5), 539-560.

Todorović, N. 2015. Content analysis of travel blogs as an identification instrument of Belgrade's tourism image elements. In: D. Filipović, S. Đurđić (eds.), The Fourth Serbian Congress of Geographers - Proceedings of young researchers, (187-192). Belgrade: University of Belgrade - Faculty of Geography. (in Serbian with English summary)

Todorović, N., Deđanski, V. 2016. Significance and location of tourist attractions in Belgrade. The Fourth Congress of Geographers of Bosnia and Herzegovina (Collection of Abstracts), 129. Faculty of natural sciences, Sarajevo. (in Serbian and English)

Wang, R., Shi, H.C., Wang, D. 2016. Spatial structure analysis of tourist attraction in lanzhou based on GIS. In: Y. Shu, G. Chang, Z. Luo (Eds.), International Conference on Education, Management, Computer and Society (EMCS 2016), (1185-1188). Shenyang: Atlantis Press.

Wang, T., Wang, L., Ning, Z.Z. 2018. Spatial pattern of tourist attractions and its influencing factors in China. Journal of Spatial Science 65(2), 327-344. DOI: 10.108o/14498596.2018.1494058

Weber, S., Mikačič, V. 1995. Determinants of attractiveness of county tourist destinations in Croatia. Tourism 43 (3-4), 52-65. (in Croatian)

Wei, W., Hua, C. J. 2012. Research on spatial structure of scenic spot in Zhejiang province based on geographic-mathematics method. Tourism Research 4(3), 39-44.

Wu, H., Gu, C., Ma, R.. Xu, X. 2003. Research on Tourism Structure Characteristics in Jiangsu Province. Scientia Geographica Sinica 23(6), 755-761.

$\mathrm{Xu}, \mathrm{B}$, Pan, J. 2019. Spatial distribution characteristics of national protected areas in China. Journal of Geographical Sciences 29(12), 2047-2068. DOI: https://doi.org/10.1007/s11442019-1704-0

Yuan, J., Yu, R.L. 2010. Research on spatial structure of national A-Grade tourist districts of Wuhan metropolitan area. Economic Geography 30(2), 324-328.

Zhao, J. 2018. Research on Spatial Distribution Characteristics and Mechanism of 4A Level and Above Tourism Scenic Spots in Henan Province. IOP Conf. Series: Earth and Environmental Science 186(6), 12-43. doi :10.1088/1755-1315/186/6/012043

Zhu, Z., Cao, J., Weng, C. 2018. Location-Time-Sociality Aware Personalized Tourist Attraction Recommendation in LBSN. In: W. Shen, J. Luo, J.P. Barthes, F. Dong, J. Zhang, H. Zhu (Eds.), IEEE 22nd International Conference on Computer Supported Cooperative Work in Design (CSCWD), (636-641). Nanjing: Institute of Electrical and Electronics Engineers. doi: 10.1109/CSCWD.2018.8465179 